\title{
Dinamika Pengisian Jabatan Presiden dan Pemberhentian Presiden dan Wakil Presiden di Indonesia
}

\author{
Sulardi \\ Fakultas Hukum Universitas Muhammadiyah Malang
}

\section{Abstract}

Power and authority of executive institute experience dynamics lead to executive institute which its reside in at system governance of presidential. Lying between election of vice president and president by people, domiciling president as governance head and president, and also mechanism cessation of president. This condition indicates that still.needed by make-up of system principles governance of presidential, so that management of governance can walk effectively and is efficient. Each state institute has to equivalent domicile and have different authority, but remain to stay in corridor check and balance.

Election dynamics of president republic of Indonesia is since Indonesia of independence to be conducted different in the way of and unequal legal fundament. Mechanism. election of president in Indonesia is first time conducted by state bodies (PPKI, MPRS, MPR). Legal consequences (which have been specified in law), and selected direct by people.

Lifting of direct selected president by people early at 1999 up to 2001, since happened alteration of the constitution 1945. One of them with related to election of president, from election of president by MPR become president selected directly by people base on section 6 A sentence (1). Election of vice president and president directly create counter balance between various strength in management of state especially in creating check and balance, among president with delegation institute because both of the same selected by people.

While for the cessation of previous president represent political mechanism. To arrest president, DPR is enough by proposing to MPR so that performing a special conference to arrest president. After alteration of the constitution 1945-mechanism cessation of president entangle state institute besides DPR and MPR, that is MK (constitution court), passing conference process just open and fair. If initially president can be arrested by because reason of collision of state having the character of politics and multi interpretation, hence in this time affirmed that president and/ or vice president can only be arrested by because just legal ground, that is: heavy transgression, conducting culpable deed, experiencing of change so that no longer eligible as president and/ or vice president. Cessation mechanism like this referred as with impeachment. Impeachment goes into effect special for president and/or vice president with term "can be arrested in a period of its position". Attendance of this section is become counterbalance of reinforcement of system of presidential post constitution amendment.

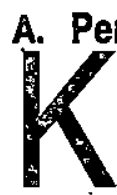
endahuluan

ekuaaan eksekutif dalam negara konstitusional di masa sekarang ini dapat diringkas sebagai berikut: (a) Kekuasan diplomatik, yaitu. berkaitan dengan hubungan luar negeri; (b) Kekuasaan administratif, yaitu berkaitan dengan pelaksanaan undang-ündang dan administrasi negara; (c) Kekuasan militer, yaitu yang berkaitan dengan organisasi bersenjata dan pelaksanaan perang; (d) Kekuasaan yudikatif, yaitu menyangkut memberi pengampunan, penangguhan hukuman dan sebagainya terhadap narapidana atau pelaku krimininal; dan (e) Kekuasaan legislatif, yaitu berkaitan dengan penyusunan rancangan undang-undang dan mengatur proses pengesahan menjadi undang-undang (Strong, 2004; Asshidiqie, 2004).

Dengan demikian, maka istilah eksekutif dipakai dalam dua pengertian. Pertama, eksekutif dalam pengertian luas, yaitu seluruh badan menteri-menteri, pelayanan sipil, polisi, dan bahkan militer. Kedua, eksekutif dalam pengertian sempit, yang berarti pemimpin tertinggi kekuasaan eksekutif.

Berdasar pada UUD 1945, maka eksekutif yang dimaksud adalah Presiden, Wakil Presiden dan para Menteri. Hal tersebut terlihat dalam Pasal 4 ayat (1): "Presiden Republik Indonesia memegang kekuasaan pemerintahan menurut Undang-Undang Dasar"; ayat (2) "Dalam melakukan kewajiban Presiden dibantu oleh satu orang Wakil Presiden. Demikian halnya yang termuat dalam UUD 1945 Pasal 17 ayat (1): "Presiden dibantu 
oleh menteri-menteri negara; ayat (2): "Menteri menteri itu diangkat dan diberhentikan oleh negara"; dan ayat (3) "Menteri-menteri itu memimpin departemen pemerintahan". Penegasan Pasal 4 ayat (1) di atas pada màsa' Orde Baru dianggap sebagai sumber kewenangan dan dipergunakan sebagai dasar dari berbagai Keputusan Presiden. Dalam tulisan Indra (1998), dijelaskan bahwa kekuasaan Presiden menurut UUD 1945 dibagi dalam empat hal, yaitu: (1) kekuasaan presiden di bidang eksekutif; (2) kekuasaan presiden di bidang legislatif ; (3) kekuasaan Presiden sebagai kepala negara; dan (4) kekuasaan presiden di bidang yudikatif.

Kekuasaan Presiden dalam bidang eksekutif dảpat dilihat pada Pasal 4 ayat (1) Jo. Pasal 5 ayat 2 UUD 1945. Pasal 4 ayat (1): "Presiden Republik Indonesia memegang kakuasaan Pemerintahan berdasar UndangUndang Dasar"; Pasal 5 ayat (2) : "Presiden menetapkan Peraturan Pemerintah untuk menjalankan Undangundang sebagaimana mestinya". Berdasar pada ketentuan ini dapat dimengerti bahwa dalam :proses pembentukan Undang-undang (law making process) hak dan wewenang Presiden jauh lebih menonjol jika dibandingkan dengan hak dan wewenang DPR. Di tangan Presiden kekuasaan membuat Undang-undang dikendalikan (Pieres, 2007).

Kekuasaan Presiden dalam bidang legislatif terlihat dari ketentuan-ketentuan yang terdapat dalam UUD 1945 yang menunjukkan bahwa presiden adalah mitra kerja DPR, artinya Presiden bekerja sama dengan DPR dalam tugas legislatif yang di antaranya adalah: membentuk Undang-undang (Pasal 5 ayat (1), Pasal 20 ayat (1), Pasal 21, dan Pasal 22 UUD 1945), serta menetapkanAnggaran Pendapatan dan Belanja Negara (Pasal 23 UUD 1945).

Kekuasaan Presiden sebagai kepala negara dapat dilihat dari pasal-pasal yang menyatakan bahwa Presiden mempunyai tugas-tugas pokok, yaitu pada: Pasal 10, "Presiden memegang kekuasaan yang tertinggi atas Angkatan Darat, Angkatan Laut, dan Angkatan Udara"; Pasal 11, "Presiden dengan persetujuan Dewan Perwakilan Rakyat menyatakan perang, membuat perdamaian dan perjanjian dengan negara lain"; Pasal 12 , "Presiden menyatakan keadaan bahaya"; Pasal 13 ayat (1) "Presiden mengangkat duta dan konsul"; ayât (2), "Presiden menerima duta negara lain", Pasal 15, "Presiden membuat gelaran, tanda jasa dan lain-lain tanda kehormatan".

Kekuasaan Presiden dalam bidang yudikatif terdapat dalam Pasal 14, "Presiden memberi grasi, abolisi, rehabilitasi, dan amnesti". Kekuasaan Presiden yang termuat dalam Undang-Undang Dasar 1945 tersebut, menunjukkan betapa sangat besarnya kekuasaan Presiden, hal tersebutlah yang menjadikan penyebab mengapa selama Orde Baru Presiden menjadi sangat dominan (Surbakti, 1998).

Di dalam UUD 1945, kekuasaan presiden sebenarnya secara dikotomi dapat dipisahkan menjadi kekuasan presiden selaku kepala pemerintahian dan kekuasaan presiden selaku kepala negara, dan masih terdapatijenis kekuasaan baru:Presiden sebagai Mandataris MPR.

Demikian besarnya kekuasaan Presiden berdasar UUD 1945 tersebut, dalam praktiknya paling tidak memunculkan dua masalah yang mendasar yang selalu menjadi perhatian pengkaji hukum tata negara. Pertama, UUD 1945 memberikan kekuasaan yang luar biasa kepada Presiden. Kedua sepanjang berlakunya UUD 1945 masa Orde Baru belum pernah dilakukan pengisian jabatan puncak eksėkutif secara "wajar" (Isra, 2003). Adanya executive heavy berdasar UUD 1945 disebabkan karena adanya dua kekuasaan sekaligus yaitu kekuasaan eksekutif dan legislatif berada di tangan presiden (Syaifudin, 2007).

Sesuai dengan prinsip perubahan UUD 1945 untuk mempertegas sistem presidensiil (Fadjar, 2006), dan dianutnya pemisahan cabang-cabang kekuasaan negara yang utama dengan prinsip checks and balance, maka perubahan UUD 1945 berakibat pula di bidang eksekutif sebagai berikut:

1. Presiden sebagai pemegang kekuasaan eksekutif Pasal 4 ayat (91) tidak lagi memegang kekuasaan membentuk undang-undang yang telah bergeser ke tangan DPR Pasal 20 ayat (1) melainkan hanya berhak mengajukan rancangan undang-undang ke DPR Pasal 5 ayat (20), memberikan persetujuan bersama dengan DPR dan mengesahkan RUU menjadi undang-undang Pasal 20 ayat (2) dan ayat (4);

2. Presiden tidak lagi dipilih oleh MPR melainkan dipilih secaralangsung oleh rakyat berpasangan dengan dari calon yang diajukan oleh partai politik atau gabungan partaipolitik (Pasal 6A);

3. Masajabatan Presiden selama 5 tahun secara tegas dibatasi untuk dua periode (Pasal 7);

4. Ditentukan syarat-syarat yang lebih rinci untuk menjadi Presiden dan Wakil Presiden (Pasal 6); 
5. Ditentukan mekanisme pemberhentian atau impeachment terhadap Presiden dan Wakil Presiden yang melibatkan DPR, MK dan MPR (Pasal 7Adan 7B);

6. Penegasan bahwa Presiden tidak dapat membubarkan DPR (Pasal7C);

7. Pelaksanaan hak-hak prerogatif Presiden sebagai. kepala negara harus dengan persetujuan atau pertimbangan DPR;

8. Pengangkatan pejabat-pejabat publik, seperti anggota BPK (Pasal 23F), Hakim Agung Pasal 24 A ayat (3), anggota KY Pasal 24B ayat (3) harus dengan persetujuan DPR;

9. Presiden berwenang membentuk dewan pertimbangan (pasal 16) sebagai pengganti DPAyang dihapuskan

10. Dalam pembentukan, pengubahan dan pembubaran kementerian harus diatur dengan undang-undang [Pasal 17 ayat (4), tidak bebas seperti sebelumnya.

Perubahan aturan yang berkenaan dengän kekuasaan Presiden itu, oleh beberapa ahli hukum tata negara disebutkan sebagai telah terjadi pergeseran dari executive heavy ke arah legislative heavy (Huda, 2003).

\section{B. Dinamika Pemilihan Presiden Republik Indonesia.}

Menurut Maurice Duverger (1987), cara-cara yang dapat digunakan untuk memilih pangreh (penguasa) dapat digolongkan menurut dua kategori:

a. Menyerahkan pemilihan orang-orang pangreh kepada orang-orang yang di-reh (dikuasai) biasanya dinamakan cara demokratis;

b. Menjauhkan orang-orang yang direh dari hal pèmilihan orang-orang pangreh dinamakan cara otokratis.

Selanjutnya cara - cara memilih penguasa yang dipilih secara otokratis ini dapat dikelompokkan ke dalam beberapa cara yaitu:

1). Perebutan kekuasaan;

2). Keturunan;

3). Kooptasi;

4).Pengundian;

5). Pengangkatan oleh pa ngreh lain.

Pemilih Presiden di negara Indonesia sejak tahun 1945 mempunyai enam presiden, yakni ; Ir Soekarno, Soeharto, B.J. Habibie, Abdurahman Wahid, Megawati Soekarnopoetri dan. Susilo Bambang Yudhoyono (SBY). Dari ke enam Presiden yang telah mewarnai jalannya negara ini ternyata cara pemilihannya dilakukan dengan cara-cara yang berbeda dan dasar hukum yang tidak sama.

Ir. Soekarno yang menjadi presiden RI dari tahun 1945 sampai dengan tahun 1966 melalui cara-cara yang berbeda dari dalam negara Indonesia yang berbeda pula. Untuk pertama kalinya menjadi presiden RI, Ir Soekarno dipilih oleh Panitia Persiapan Kemerdekaan Indonesia, hal ini berdasar pada Aturan Peralihan Pasal III UUD 1945 yang berbunyi: untuk. pertama kalinya presiden dan wakil presiden dipilih oleh PPKI. Kedudukan sebagai presiden yang dipilih oleh PPKI ini hanya bertahan selama empat tahun. Pada saat terjadi perubahan negara Indonesia dari negara kesatuan menjadi negara serikat dari tanggal 27 Desember 1945 sampai dengan 17 Agustus 1950 Ir Soekarno kembali menjadi presiden berdasar pada ketentuan Pasal 69 ayat (2) Konstitusi RIS bahwa "Beliau dipilih oleh orang orang yang dikuasakan oleh pemérintah daerah-daerah bagian".

Negara serikat yang hanya berusia delapan bulan, pada tanggal 17 Agustus 1950 perubahan negara kembali terjadi, Indonesia menjadi negara kesatuan berdasar pada UUD Sementara tahun 1950. Ir Soekarno tetap menjadi presiden berdasar pada ketentuan aturan Pasal 141 UUD S 1950, hanya saja kedudukan presiden pada periode ini hanya sebagai kepala negara. Kepala pemerintahan dijalankan oleh Perdana Menteri. Pada masa ini sistem pemerintahan menggunakan sisitem parlementer. Situasi pemerintahan yang dijalankan dengan cara demokrasi liberal itu, bertahan hingga tahun 1959, setelah Ir Soekarno mengeluarkan Dekrit Presiden pada tanggal 5 Juli 1959 Indonesia kembali sebagai negara kesatuan berdasar pada UUD 1945. Ir. Soekarno tetap menjadi presiden, kali ini berdasar pada aturan peralihan pasal II UUD 1945, bahwa: "Badan negara dan Peraturan yang ada masih langsung berlaku selama belum diadakan yang baru menurut UUD inr". Di antara cara 
pengangkatan Ir. Soekarno menjadi presiden tersebut, terdapat pula ketentuan hukum sebagai penguatan kedudukan presiden, yakni Ketetapan MPRS No III/MPRS/1963 tentang Pengangkatan Ir Soekarno sebagai presiden seumur hidup. Hal tersebut mejelaskan bahwa Ir Soekarno menjadi.presiden melalui berbagai caraiyang berbeda.

Presiden kedua Rl, Soeharto, yang menjadi presiden selama 32 tahun dari tahun 1966 sampai dengan tahun 1998. Naiknya Soeharto menggunakan satu cara, yaitu melalui pengangkatan pada tahun 1966 diangkat sebagai pejabat presiden oleh MPRS. Setahun kemudian pada tahun 1967 oleh MPRS, Soeharto diangkat lagi sebagai presiden. Setelah itu sejak tahun 1973 sampai dengan tahun 1998, Soeharto diangkat menjadi presiden setiap lima tahun sekali berdasar pada Ketetapan MPR No II MPR Tahun 1973 tentang Tata Cara Pemilihan Presiden dan Wakil Presiden, yang di dalamnya memuat ketentuan, bahwa jika calonnya tunggal maka calon tersebut langsung diangkat oleh MPR sebagai presiden.

Presiden ketiga negeri ini, yakni B.J. Habibie menjadi presiden selama 2 tahun 6 bulan merupakan presiden yang tidak melalui pemilihan dạn atau pengangkatan, tetapi menjadi presiden melalui mekanisme "presiden demi hukum". Habibie menjadi presiden melalui berdasarkan Pasal 8 UUD 1945, yakni: "Jika Presiden mangkat, berhenti atau tidak dapat menjalankan kewajibannya dalam masa jabatannya, maka diganti oleh Wakil Presiden sampai habis masa jabatannya". Berdasar pada pasal tersebut, tidak ada kekuatan apa pun yang mampu menahan atau menolak Habibie sebagai Presiden RI ketiga. Cara ini juga yang dijadikan dasar ketika Megawati Soekarnopoetri menjadi presiden kelima RI, menggantikan KH Abdurrahman Wahid (Gus Dur). Abdurrahman Wahid merupakan presiden RI keempat yang prosesnya melalui ketentuan Pasal 6 UUD 1945, bahwa "Presiden dipilih oleh MPR dengan suara terbanyak".

Pada tahun 1999 sampai dengan tahun 2001 terjadi perubahan UUD 1945, salah satunya berkenaan dengan pemilihan presiden, dari pemilihan presiden oleh MPR menjadi presiden dipilih secara langsung|oleh rakyat berdasar pada Pasal 6 Aayat (1)

"Presiden dan Wakil Presiden dipilih dalam satu pasangan secara langsung oleh rakyat. Ayat (2): "Pasangan calon Presiden dan Wakil Presiden diusulkan oleh partai politik atau gabungan partai politik peserta pemilihan umum sebelum melaksanakan pemilihan umum. Ayat (3): "Pasangan calon Presiden dan Wakil Presiden yang mendapatkan suara lebih dari lima puluh persen dari jumlah suara di setiap provinsi yang tersebar di lebih dari setengah jumlah propinsi di Indonesia, dilantik menjadiPresiden dan Wakil Presiden".

Menurut Saldi Isra (2003), dari berbagai cara pemilihan Presiden yang berbeda-beda itu, Presiden yang dipillh melalui pemilihan langsung akan mendapat mandat dan dukungan yang lebih nyata dari rakyat sebagai wujud kontrak sosial antara pemilih dengan tokoh yang dipilih. Kemauan orang-orang yang memilih akan menjadi pegangan bagi Presiden dalam melaksanakan kekuasaannya. Pemilihan secara langsung akan menghindari intrik-intrik politik dalam proses pemilihan secara perwakilan. Pemilihan Presiden dan Wakil Presiden secara langsung menciptakan perimbangan antara berbagai kekuatan dalam penyelenggaraan negara terutama dalam menciptakan checks and balances antara Presiden dengan lembaga perwakilan karena sama-sama dipilih oleh rakyat.

\section{Dinamika Pemberhentian Presiden dan/atau Wakil Presiden}

Mekanisme pemberhentian Presiden dan/atau Wakil Presiden sebelumnya diatur dalam TAP MPR No. VI/MPR/1973 tentang Kedudukan dan Hubungan Tata Kerja Lembaga Tinggi Negara dengan/antar LembagaLembaga Tínggi Negara. Dalam perkembangannya aturan itu diubah dengan TAP MPR No. Ill/MPR/1978. Mèlalui aturan ini, mekanisme pemberhentian Presiden betul-betul merupakan mekanisme politik. Untuk memberhentikan Presiden, DPR cukup dengan mengusúulkan kepada MPR agar mengadakan Sidang Istimewa untuk memberhentikan Presiden.

Hal tersebut menyebabkan proses pemberhentian Presiden dan atau Wakil Presiden memakan waktu cukup panjang karena melalui memorandum DPR hingga tiga kali sebagai persyaratan digelarnya Sidang Istimewa untuk meminta pertanggungjawaban Presiden. Model ini sesungguhnya tidak fair dan tidak adil. Sèbab 
dalam Sidang Istimewa MPR, MPR bertindak sebagai jaksa sekaligus sebagai hakim, menuntut Presiden sekaligus menjatuhkan vonis memberhentikan Presiden.

Setelah perubahan UUD 1945, mekanisme pemberhentian Presiden melibatkan lembaga negara selain DPR dan MPR, yaitu MK, melalui proses persidangan yang terbuka adil dan fair. Jauh-jauh hari sebelum pemberhentian Abdurrahman Wahid melalui Sidang Istimewa Juli 2001, Presiden Republik Indonesia yang diberhentikan pada masa jabatannya adalah Presiden Soekarno melalui Sidang MPR Sementara pada tanggal 22 Juni 1966. Pada masa itu pertanggungjawaban Soekarno yang disebut dengan pidato nawaksara ditolak oleh MPRS. Ketua MPRS menyampaikan nota kepada Presiden Soekarno, yang di dalamnya meminta agar Presiden Soekarno mempertanggungjawabkan sebab-sebab terjadinya G-30 S/PKI, beserta epilognya, pertanggungjawaban ekonomi dan kemerosotan akhlak bangsa Indonesia Setelah menambahkan seperti apa yarig diminta oleh MPRS, tetap saja MPRS tidak menerima. Karena itu Soekarno harus berhenti menjadi Presiden melalui Ketetapan MPRS No XXXIII/MPR/1967. Di dalam Pasal 1 dinyatakan bahwa Presiden telah tidak dapat memenuhi pertanggungjawabkan secara konstitusional, sebagaimana layaknya seorang mandataris. Terhadap penolakan pertanggungjawaban itu, Suwoto (1997) mempertanyakan apakah pertanggungjawaban terhadap kemerosotan akhlak dan kemerosotan ekonomi, serta terjadinya G - 30 S/PKI adalah pertanggungjawaban konstitusional. Pertanyaan tersebut sampai saat ini belum terjawab.

Sedangkan Presiden Soeharto tidak pernah diberhentikan oleh MPR melalui Sidang Istimewa, bahkan pertanggungjawaban Seharto selalu diterima oleh MPR. Tetapi Presiden Soeharto berhenti dalam masa jabatannya melalui mekanișme Pasal 8 UUD 1945, bahwa : Jika Presiden mangkat, berhenti, atau tidak dapat melakukan kewajibannya dalam masa jabatannya, ia diganti oleh Wakil Presiden sampai habis waktunya". Pada tanggal 20 Mei 1998 Presiden Soeharto menyatakan berhenti menjadi Presiden setelah adannya desakan mundur dari masyarakat yang dimotori oleh mahasiswa begitu gencar. Sesaat kemudian berdasar pada pasal 8 UUD 1945 tersebut, BJ Habibie menggantikannya.

Dua mekanisme pemberhentian Presiden yang dialami oleh Abdurahman Wahid dan Soekarno adalah pemberhentian melalui sidang yang bersifat tunggal, "jaksa" dan "hakim" adalah pihak yang sama, yaitu MPR. Dengan model seperti itu siapa pun yang menjadi Presiden ketika dihadapkan pada sidang Istimewa MPR pastilah berhenti, sekuat apapun Presiden itu.

Lain halnya pemberhentian Presiden di Amerika Serikat, mekanisme pemberhentian Presiden Amerika Serikat dikemukakan di sini guna membandingkan mekanisme yảng lebih adil dan fair. Di mana Konstitusi Amerika Serikat memungkinkkan terjadinya pemberhentian Presiden melalui mekanisme yang dinamai impeachment. Ketentuan itu diatur dalam Bab IV Pasal 2: "Bahwa Presiden, Wakil Presiden dan para pegawai negeri sipil Amerika Serikat akan diberhentikan dari masa jabatnnya berdasarkan impeachment karena dan telah terbuktimelakukan pengkhianatan, penyuapan atau tindak kriminal tingkat tinggi".

Ketentuan pasal tersebut menunjukkan bahwa proses pemberhentian Presiden melalui proses persidangan, dengan demikian Presiden dapat terlepas dari pemberhentian dalam masa jabatannya bila ternyata apa yang disangkakan atau dituduhkan tidak terbukti. Sejauh ini baru tiga Presiden yang terkena impeachment tersebut. Pertama adalah Presiden Andrew Johnson pada tahun 1968, namun pemungutan suara yang dilakukan oleh Senat Amerika Serikat waktu itu tidak memenuhi ketentuan untuk menghantar pada pemberhentian Presiden Andrew Johnson ini. Kedua pada tahun 1974 Nixon yang dituduh melakukan skandal watergate: Namun Nixon mengundurkan diri sebelum proses impeachment berlangsung. Ketiga adalah Presiden Bill Clinton pada tahun 1999, dengan kasus sumpah palsu atas skandal Monica Lewinsky. Bill Clinton selamat dari pemberhentian Presiden sebab 55 dari 100 anggota Senat menyatakan bahwa Bill Clinton tidak bersalah.

Dua mekanisme pemberhentian Presiden di Amerika Serikat dan di Indonesia menunjukkan model yang berbeda, yang satu Presiden mempunyai ruang untuk terlepas dari jeratan pemberhentian sebagai Presiden. RI 1945:

Ketentuan mengenai pemberhentian Presiden dan atau Wakil Presiden diatur dalam pasal.7AUUD Negara

"Presiden dan latau Wakil Presiden dapat diberhentikan dalam masa jabatannya oleh Majelis Permusyawaratan Rakyat atas usul Dewan Perwakilan Rakyat, baik apabila terbukti telah melakukan pelanggaran hukum berupa pengkhianatan terhadap negara, korupsi, penyuapan, tindak pidana berat lainnya, 
atau perbuatan tercela, maupun apabila terbukti tidak lagi memenuhi syarat sebagai Presiden dan/atau Wakil Presiden".

Kalau semula Presiden dapat diberhentikan karena alasan pelanggaran negara yang bersifat politik dan multi tafsir, maka sekarang ini ditegaskan bahwa Presiden dan/atau Wakil Presiden hanya dapat diberhentikan karena alasan hukum saja, yaitu: pelanggaran hukum berat, melakukan perbuatan tercela, mengalami perubahan sehingga tidak lagi memenuhi syarat sebagai Presiden dan/atau wakil Presiden. Yang menjadi persoalan adalah alasan perbuatan tercela yang tidak begitu jelas ukurannya (Asshiddiqie, 2002).

Mekanisme pemberhentian seperti yang diatur dalam asal 7B UUD Negara RI 1945 menyatakan :

1. Usul pemberhentian Presiden dan/atau Wakil Presiden dapat diajukan oleh Dewan Perwakilan Rakyat kepada Majelis Permusyawaratan Rakyat hanya dengan terlebih dahulu mengajukan permintaan kepada Mahkamah Konstitusi untuk memeriksa, mengadili, dan memutus pendapat Dewan Perwakilan Rakyat bahwa Presiden dan/atau Wakil Presiden telah melakukan pelanggaran hukum berupa pengkhianatan terhadap negara, korupsi, penyuapan, tindak pidana berat lainnya, atau perbuatan tercela; dan/atau pendapat bahwa Presden dan/atau wakil Presiden tidak lagi memenuhi syarat sebagai Presiden dan/atau Wakil Presiden.

2. Pendapat Dewan Perwakilan Rakyat bahwa Presiden dan/atau Wakil Presiden telah melakukan pelanggaran hukum tersebut ataupun telah tidak lagi memenuhi syarat sebagai Presiden dan/atau wakil Presiden adalah dalam rangḳa pelaksanaan fungsi pengawasan Dewan Perwakilan Rakyat.

3. Pengajuan permintaan Dewan Perwakilan Rakyat kepada Mahkamah Konstitusi hanya dapat dilakukan dengan dukungan sekurang-kurangnya 2/3 dari jumlah anggota Dewan Perwakilan Rakyat yang hadir dalam sidang paripurna yang dihadiri oleh sekurang-kurangnya $2 / 3$ dari jumlah anggota Dewan Perwakilan Rakyat.

4. Mahkamah Konstitusi walib memeriksa , mengadili, dan memutus dengan seadil-adilnya terhadap pendapat Dewan Perwakilan Rakyat tersebut paling lama sembilan puluh hari setelah permintaan Dewan Perwakilan Rakyat itu diterima olehMK.

5. Apabila Mahkamah Konstitusi memutuskan bahwa Presiden dan atau / Wakil Presiden terbukti melakukan pelanggaran. hukum berupa pengkhianatan terhadap negara, korupsi, penyuapan, tindak pidana berat lainnya, atau perbuatan tercela; dan/atau terbukti bahwa Presiden dan/atau Wakil Presiden tidak lagi memenuhi syarat sebagai Presiden dan/atau Wakil Presiden, Dewan Perwakilan Rakyat menyelenggarakan sidang paripuma untuk meneruskan usul pemberhentian Presiden daniatau Wakil Presiden kepada Majelis Permusyawaratan Rakyat.

6. Majelis Permusyawaratan Rakyat wajib menyelenggarakan sidang untuk memutuskan usul Dewan Perwakilan Rakyat tersebut paling lambat tiga puluh hari sejak Majelis Permusyawaratan Rakyat menerima usul tersebut.

7. Keputusan Majelis Permusyawaratan Rakyat atas usul pemberhentian Presiden dan/atau Wakil Presiden harus diambil dalam rapat paripurna Majelis Permusyawaratan Rakyat yang dihadiri oleh sekurang-kurangnya $3 / 4$ dari jumlah anggota dan disetujui oleh sekurang-kurangnya $2 / 3$ dari jumlah anggota yang hadir, setelah Presiden dan/atau Wakil Presiden diberi kesempatan menyampaikan penjelasan dalam rapat paripurna Majelis Permusyawaratan Rakyat.

Menurut Asshiddiqie (2002), sehubungan dengan keputusan untuk memberhentikan ini dapat dikembangkan dua kemungkinan pendapat. Pertama, keputusan untuk memberhentikan merupakan kewajiban yang harus dilakukan oleh MPR. MPR wajib menjalankan Kedaulatan Rakyat menurut UUD yang menentukan bahwa sebelum pemberhentian, perlu diputuskan dulu bersalah tidaknya yang bersangkutan oleh MK. Artinya, peran MK diperlukan dalam rangka menjamin agar proses pemberhentian Presiden sebagai akibat pendapat yang berisi penuntutan oleh DPR dapat diputuskan secara hukum dan karena alasan hukum. Dengan demikian, MPR terikat untuk memberhentikan yang bersangkutan dari jabatannya, apabila yang bersangkutan memang terbukti bersalah. Artinya, tidak boleh terjadi MK menyatakan yang bersangkutan bersalah, tetapi Majelis Permusyawaratan Rakyat tidak memberhentikannya dari jabatan. Kedua, Jika menurut MK, Presiden / wakil 
Presiden memang terbukti bersalah, MPR lah yang akan menjatuhkan sanksi pemberhentian dengan beberapa kemungkinan kualifikasi, diberhentikan tidak dengan hormat, atau diberhentikan dengan hormat: Misalnya, pemberhentiàn karena Presiden berubah menjadi cacat dan tidak memenuhi syarat lagi sebagai Presiden. Jika hal tersebut terbukti dengan putusan MK ia dinyatakan tidak lagi memenuhi syarat, maka kualifikasi pemberhentiannya dapat berupa pemberhentian dengan hormat.

Disamping itu, meskipun Presiden/ wakil Presiden misalnya memang terbukti bersalah atau tidak lagi memenuhi syarat sebagai Presiden, bisa saja karena pertimbangan kemanusiaan atau pertimbangan kepentingan umum lainnya, MPR justru tidak memberhentikan melainkan hanya menghukum dengan cara mendiskualifikasikannya dari pencalonan untuk periode berikutnya. Dapat pula terjadi setelah diperolehnya putusan MK, masa jabatan Presiden yang bersangkutan hanya tinggal 2 bulan lagi menjelang pelaksanaan pemilihan umum, maka atas dasar pertimbangan kepentingan umum, MPR tidak memberhentikan Presiden tetapi hanya mendiskualifikasi statusnya sehingga ia tidak dibolehkan mencalonkan diri untuk jabatan berikutnya. Tetapi masa kepresidenannya yang tinggal 2 bulan dapat saja diteruskan.

Dengan kata lain putusan MK dibatasi hanya menyangkut soal pembuktian hukum, sedangkan putusan MPR berkenaan dengan penjatuhan sanksi terhadap terhukum, sementara peran DPR dapat dibaratkan seakanakan seperti peranan jaksa penuntut umum. Sekalipun demikian, Slamet Effendy Yusuf (wawancara tanggal 4 Juni 2008) memiliki pendapat yang berbeda, sebab bisa terjadi MPR bisa berbeda pendapat dengan MK, sebab keputusan MPR adalah keputusan politik, tetapi karena masa jabatan Presiden dan/atau Wakil Presiden tinggal satu tahun, maka bisa saja keputusan politiknya berbunyi Presiden dinyatakan bersalah tetapi tidak diberhentikan sebagai Presiden dan /atau Wakil Presiden, tetapi diampuni, dan tidak boleh mencalonkan kembali. Tetapi jika logika politik yang digunakan pastilah Presiden dan/atau Wakil Presiden diberhentikan.

Dari mekanisme pemberhentian Presiden dan atau Wakil Presiden seperti yang dikemukakan tersebut di atas, menurut Mahfud MD (2007), menunjukkan bahwa pemberhentian Presiden dan Wakil Presiden menggunakan sistem campuran antara impeachment dan sistem forum previlegiatun. Impeachment menunjukan bahwa presiden dijatuhkan oleh lembaga politik yang mencerminkan wakil seluruh rakyat. Sedangkan previlegiatun adalah menjatuhan presiden melalui pengadilan khusus ketatanegaraan yàng dasarnya adalah pelanggaran hukum berat yang ditentukan di dalam konstitusi dengan putusan hakim pula.

Mahfud MD (2010), menyatakan bahwa berkenaan dengan mekanisme pemberhentian presiden dan wakil presiden terdapat dua pendapat, pertama pendapat yang dikemukakan Hajriyanto Y. Thohari, Wakil Ketua MPR. Menurut pendapat ini, impeachment harus dimulai dari hak menyatakan pendapat DPR terkait tuduhan pelanggaran hukum yang dilakukan presiden atau wapres. Hak menyatakan pendapat ini harus diputuskan melalui paripurna DPR yang dihadiri minimal $3 / 4$ anggota dan disetujui $3 / 4$ anggota yang hadir. Bila disetujui, selanjutnya dibentuk pansus. Rekomendasi pansus hak menyatakan pendapat kembali dibahas paripurna yang dihadiri minimal 2/3 anggota dan disetujui $2 / 3$ anggota yang hadir. Bila disetujui, DPR baru akan menyampaikan ke MK. Kalau kuorum tidak tercapai, berarti penggunaan hak itu tidak bisa diteruskan alias mentok.

Kedua, ialah pendapat yang dikemukakan, ahli hukum ṕidana UGM, Eddy O.S. H, bahwa harus ada vonis pengadilan pidana yang mempunyai kekuatan hukum tetap, yang menyatakan bahwa yang bersangkutan, presiden atau wapres bersalah. Setelah itu proses impeachment bisa dimulai. Hasil pemeriksaan pansus DPR bukan merupakan bukti hukum melainkan hanya indikasi atau produk politik belaka. Untuk itu, Pansus DPR perlu membuktikan indikasi tersebut melalui penyelidikan secara projustisia oleh aparathukum.

Berdasar pada UUD Negara RI 1945, maka segala pemeriksaan terhadap presiden dan wakil presiden setelah pendapat DPR diajukan kepada MK. Secara demikian, apabila yang diajukan oleh DPR adalah perkara pidana, maka pemeriksaan masalah pidana dilakukan setelah proses impeachmentselesai.

Keputusan akhir dalam pemberhentian Presiden tetap berada pada sidang MPR. Dimana dalam pengambilan keputusan dilakukan secara politis, yakni dihadiri 3/4 anggota MPR dan pengambilan keputusan harus disetujui paling sedikit 2/3 anggota yang hadir. Cara-cara ini menurut Abdul Hakim Garuda Nusantara (2002) lebih memenuhi asas kepastian hukum dan checks and balances, juga menunjukkan sistem presidensiil lebih terlihat, karena dalam sistem presidensil tidak boleh ada motif politik yang dijadikan prasyarat pemberhentian Presiden dan/atau Wakil Presiden (Haryadi, 2002). Sedangkan menurut Absori (Suara Merdeka, 11 Juli 2002), Hal tersebut menunjukkan tidak ada sistem presidensiil secara penuh, yang ada adalah sistem quasi 
presidensil. Dengan alasan DPR atau MPR masih mempunyai kewenangan untuk melakukan intervensi, bahkan bisa menjatuhkan presiden dan atau wakil presiden. Berbeda halnya dengan pandangan Benny K. Harman (16 Maret 2008) yang menyatakan bahwa, pemurnian sistem presidensill setelah perubahan UUD 1945 tidak mereduksi fungsi parlemen dalam menjalankan tugas pengawasan terhadap jalannya pemerintahan oleh presiden, agar presiden tidak mudah menyalahgunakan kekuasaan.

Dalam makalahnya pada Round Table Discussion: "Framework for Impeachment Proceedings" di Universitas Sriwijaya di Palembang, Jumat, 9 April 2010, Mahfud MD menyebut bahwa:

"Indonesia mengadopsi mekanisme impeachment yang obyeknya hanya menyangkut Presiden dan/atau Wapres. Dalam Pasal 7A itu disebutkan, impeachment berlaku khusus untuk presiden dan/atau wakil presiden dengan istilah "dapat diberhentikan dalam masa jabatannya". Kehadiran pasal ini menjadi pengimbang|atas penguatan sistem presidensill pasca amandemen konstitusi".

Pada intinya pemberhentian Presiden dan Nakil Presiden melalui tahapan politik dan hukum merupakan kemajuan dalam penyelenggaraan ketatanegaraan di Indonesia.

\section{Penutup}

Dinamika Pemilihan Presiden Republik Indonesia sejak Indonesia merdeka dilakukan dengan cara-cara yang berbeda dan dasar hukum yang tidak sama. Mekanisme pemilihan presiden di Indonesia kali pertama dilakukan oleh Badan - badan Negara (PPKI, MPRS, MPR), Akibat Hukum (yang teläh ditetapkan dalam Undang - undang), dan dipilih langsung oleh rakyat.

Pengangkatan presiden yang dipilih langsung oleh rakyat berawal pada tahun 1999 sampai dengan tahun 2001 manakala terjadi perubahan UUD 1945, salah satunya berkenaan dengan pemilihan presiden! dari pemilhan presiden oleh MPR menjadi presiden dipilih secara langsung oleh rakyat berdasar pada Pasal $6 A^{\prime}$ ayat (1). Pemilihan Presiden dan Wakil Presiden secara langsung menciptakan perimbangan antara berbagai kekuatan dalam penyelenggaraan negara terutama dalam menciptakan checks and balances, antara Presiden dengan lembaga perwakilan karena sama-sama dipilih oleh rakyat.

Sedangkan untuk pemberhentian presiden sebelumnya merupakan mekanisme politik. Untuk memberhentikan Presiden, DPR cukup dengan mengusulkan kepada MPR agar mengadakan Sidang Istimewa untuk memberhentikan Presiden. Setelah perubahan UUD 1945 mekanisme pemberhentian Presiden melibátkan lembaga negara selain DPR dan MPR, yaitu MK, melalui proses persidangan yang terbuka adil dan fair. Kalau semula Presiden dapat diberhentikan karena alasan pelanggaran negara yang.bersifat politik dan multi tafsir, maka sekarang ini ditegaskan bahwa Presiden dan/atau Wakil Presiden hanya dapat diberhentikan karena alasan hukum saja, yaitu: pelanggaran hukum berat, melakukan perbuatan tercela, mengalami perubahan sehingga tidak lagi memenuhi syarat sebagai Presiden dan/atau wakil Presiden. Mekanisme pemberhentian seperti ini disebut dengan impeachment. Impeachment berlaku khusus untuk presiden daan/atau wakil presiden dengan istilah "dapat diberhentikan dalam masa jabatannya". Kehadiran pasal ini menjadi pengimbang atas penguatan sistem presidensiil pasca amandemen konstitusi

\section{Daftar Pustaka}

Absori, "Amandemen UUD dan Kepentingan Politik" Harian Suara Merdeka edisi 11 Juli 2002.

Agus Haryadi (2002). Bikameral Setengah Hati, dalam Mochtar Pobotingi dan Abdul Mukthie Fadjar, Konstitusi BaruMelaluiKomisi Konstitusildependen, Jakarta: Sinar Harapan.

Asshiddiqie, Jimly (2002) Konsolidasi Naskah UUD 1945. Setelah Perubahan Keempat. Jakarta: Pusat Studi Hukum Tata Negara Fakultas Hukum Universitas Indonesia.

Asshidiqie, Jimly (2004) Format Kelembagaan Negara dan Pergeseran Kekuasaan dalam UUD. Yogyakarta:FHUII Press. 
Attamimi, A. Hamid S. (1990). Peranan Keputusan Presiden RI dalam Penyelenggaraan Pemerintah Negara, Disertasi Universitas Indonesia, Jakarta.

Chaidir, Ellydar (2005) Sistem Pemerintahan Negara Republik Indonesia Setelah Perubahan Undang-Undang Dasar 1945, Disertasi pada Program Pascasarjana Program Doktor llmu Hukum, Universitas Islam Indonesia, Yogyakarta.

Duverger, Maurice (1987) Teoridan Praktek Tata Negara. Jakarta: Pustaka Tinta Mas.

Fadjar, Mukhtie (2006) Hukum Konstitusi dan Mahkamah Konstitusi. Jakarta: KonPress Citra Media.

Harman, Benny K. "Kabinet dan Purifikasi Sistem Presidensil" Kompas, edisi 16. ' Maret2008.

Huda, Ni'matul (2003) Politik Ketatanegaraan Indonesia. Yogyakarta: FHUII Press.

Isra, Saldi. "Amandemen Lembaga Legislatif dan Eksekutif Prospek dan Tantangan", dalam Jurnal Unisia, No 49/XXV//II//2003, Universitas Islam Indonesia

Kusnardi, Muh dan Harmaily lbrahim.(1980) Pengantar Hukum Tata Negara. Jakarta: Pusat Studi Hukum Tata Negara Universitas Indonesia.

Mahfud MD, Moh. (2007) Perdebatan Ketatanegaraan PascaAmandemen Konstitusi. Jakarta: LP3ES.

Mahfud MD, "Impeachment menurut Konstruksi dan Logika dan sistem UUD 1945", Makalah Ceramah Kunci pada Round Table Discussion: 'Framework for Impeachment Proceedings di Universitas Sriwijaya, Palembang, Jumat, 9 April 2010

Montesquieu (2007) The Spirit of Law, Dasar Dașar Hukum dan IImu Politik. (Penerjemah M Khoirul Anam). Bandung:PTNusa Media.

Nusantara, Abdul Hakim Garuda (2002). Pemberhentian Presiden dan/atau Wakil Presiden MenurutAmandemen III UUD 1945, dalam Mochtar Pobotingi dan Abdul Mukthie Fadjar; Konstitusi Baru Melalui Komisi Konstitusi Idependen. Jakarta: Sinar Harapan.

Pieres, John (2007) Pembatasan Konstitusional Kekuasaan Presiden Rl. Jakarta:Pelangi Cendekia.

Strong, CF (2004). Konstitusi Kónstitusi Politik Modern: Kajian Tentang Sejarạh dan Bentuk-bentuk Konstitusi Dunia. Bandung: Nuansa dan Nusamedia.

Surbakti, Ramlan (1998) Reformasi Kekuasaan Presiden. Jakarta: Grasindo.

Suwoto (1997) Peralihan Kekuasaan Kajian Teoritis dan Yuridisterhadap Pidato Nawaksara. Jakarta: Gramedia.

Syaifudin (2007) "Kajian terhadap Perubahan UUD' 1945: Studi Tentang Sistem Pemerintahan Negara", dalam Kontribusi Pemikiran untuk 50 Tahun ProfDRMoh. Mahfud MD. Yogyakarta: FH-UII Press. 